УДК: 821.111-3:81'373.23'42

DOI: $10.31891 / 2415-7929-2019-19-2$

NAZARENKO O., CHASOVSKYKH A.

Sumy State University

\title{
LEXICO-SEMANTIC ANALYSIS OF ANTHROPONYMS IN MODERN ENGLISH PROSE
}

\begin{abstract}
The article studiesthe lexical and semantic features of the anthroponyms in the modern English prose discourse, basing on the material of The Mortal Instruments, series of six young adult fantasy novels, written by Cassandra Claire. The work presents origin analysis of the characters ' names and surnames presented in the books, and the ways of their interpretation.

Particular attention was paid to the information and stylistic functionality of onyms and their impact on the reader's knowledge of the inner world of the characters. We proved the connection between the choice of one's own name and the character's behavior, his or her actions and a complex socio-psychological portrait; and determined the interdependence between the use of different forms of the name, its short forms or complete replacement, from the metamorphoses that occur with the characters during the development of the plot line of the novel.

The work studies the notion of allusion as a kind of intertextuality through the collaboration of biblical and mythological motives, which in turn contributed not only to the specifics of the names 'choice of some characters, but also determined their role and order of decisions.

It is emphasized the importance of in-depth study of anthroponyms in modern English prose, taking into account the diversity of their role within the work of art, the ability to reflect the culture and social life of society, focusing on the hidden symbolism and literary heritage of a culture and country in general.
\end{abstract}

Keywords: anthroponyms, onyms, onomastics, intertextuality, modern English prose discourse, proper names.

НАЗАРЕНКО О. В., ЧАСОВСЬКИХ А. А.

Сумський державний університет

\section{ЛЕКСИКО-СЕМАНТИЧНІ ОСОБЛИВОСТІ АНТРОПОНІМІВ СУЧАСНОЇ АНГЛІЙСЬКОЇ ПРОЗИ}

\begin{abstract}
у статті розглядаються лексико-семантичні особливості англійського антропонімікону у сучасному літературному дискурсі - на матеріалі серії романів-фентезі Кассандри Клер «Знаряддя Смерті». у роботі було проведено аналіз походження, представлених у творах імен та прізвищ персонажів, розглянено способи їх тлумачення, з урахуванням авторського задуму та мовленнєвого забарвлення. Особливу увагу було приділено інформаційно-стилістичному функціоналу онімів та їх впливу на пізнання читачем внутрішнього світу літературного героя, його вчинків та комплексного соціальнопсихологічного портрета.

Ключові слова: антропоніми, оніми, ономастика, інтертексуальність, сучасний англомовний прозовий дискурс,
\end{abstract} власні імена.

Relevance of research. The article is devoted to the topic of proper names as the important part of the modern English prose discourse. The nature of proper names, their functions, the origin, development, connections with all levels of the language, as well as geographical, historical, ethnographic, cultural, sociological, literary, psychological and other aspects of their usage are studied by onomastics.

Analysis of recent scientific papers. Problems of definition and analysis of anthroponyms' linguistic nature have been discussed by well-known linguists, such as D. Salimova, A. Selishcheva, A. Sobolev, A. Gardiner, A. Dauzat, P. Reyney, W. Taschizk and others.

Formulation of the problem. The subject of the article is lexico-semantic content of anthroponyms in modern English prose that helps to understand narrator's message and special features of the characters to addressee completely. The relevance of the topic is connected with the constantly growing interest of linguists in the semantic, lexical, and communicative meaning of proper names in the modern prose literature.

The aim of the article is to investigate lexico-semantic characteristics and proper names influence on the readers as well as to differentiate specifications of their usage in English prose discourse. The importance of research is to draw the reader's attention to the hidden meaning of literary heritage. Books help us to understand the culture and mentality of this or another country deeper, reveal the characteristics of different nations. The object of researching is proper names.

Presenting the main material. Proper names have a special meaning in the language; and they are not subject to certain laws characteristic of common names. Onyms always reflect the culture and social life of society. They also convey to the addressee information and knowledge about the place and position of the individual in society. The name encodes the nationality, gender, age and marital status of the person. Literary anthroponyms that exist in prose fairy tale discourse are numerous and diverse. The real, existing world is reflected in anthroponyms, which are formed according to current morphological, word-formation, lexical and semantic models in the language. Entering into various syntagmatic and paradigmatic contacts, names provide relevance of the text, reproduce a complex hierarchy of relations of objects of reality, and orient the reader in space and time [1, p. 51;2, p. 11]. 
Most of the anthroponyms in the prose texts are etymologically "speaking", forming a holistic perception of the works. They create, first of all, the general panorama of the story, paint the most certain portrait of characters and vividly describe the background of the surrounding reality. Through the limbeck of the characters ' proper names readers deeply understand the hidden corners of their souls, comprehend the reasons of some weird actions and made decisions. Furthermore, for author it takes not just a high degree of fantasy, but also great erudition, significant philosophical world outlook and deep interest into historical, literary, cultural and psychological features of different countries.

Since the article is devoted to the study and analysis of anthroponyms in the modern English prose, we decided to focus our attention on The Mortal Instruments, series of six young adult fantasy novels, written by the American writer Cassandra Clare in the style of science fiction and urban fantasy. The events of the books are built on the existence of the so-called Shadow World - a part of reality, usually hidden from human eyes with the help of sacred runes, spells and various protective barriers that mentally affect the perception of ordinary people. The main characters of the story are divided into several groups (each of which is interesting and unusual in its own way): demons, werewolves, vampires, warlocks, angels, fairies, and Nephilims, as well as ordinary people.

Cassandra Clare's world is strongly connected to the culture of Christianity and the Bible, more namely the Old Testament. She deeply researched the mythologies of many cultures and read several works on "old" demonologies with an eye to understand the logic and background of demonic legends [3].

Thus the name Valetine comes from the Roman cognomen Valentinus which was itself from the name Valens meaning "strong, vigourous, healthy" in Latin [4]. Sebastian is the name, derived from Sebastinus, which comes from the Greek city Sebaste. Furthermore, from ancient Greek "sebastós" Sebastian means "venerable".

The surname Morgenstern is derived from the Middle German words "morgen" meaning "morning” and "stern" meaning "star". Combined the name means "one who lived at the sign of the morning star" [5].

To emphasize their greatness and majesty, Sebastian and his father Valentine had both learned to take quite literally and accept as the history of their family the Bible verse Isaiah 14:12, which states: "How art thou fallen from heaven, O Lucifer, son of the morning! How art thou fallen from heaven, O Lucifer, son of the morning! How art thou cut down to the ground, which didst weaken the nations!" [3; 6; 7].

In addition, in the last book City of Heavenly Fire, Alec Lightwood, one of the characters-Niphilims, described to his friends meaning of the surname Morgenstern: " "The morning star' means a lot of things. It can mean 'the brightest star in the sky,' or it can mean "heavenly fire," or it can mean "the fire that falls with angels when they're cast down out of Heaven." It's also the name of Lucifer, the light-bringer, the demon of pride." [3; 7; 8].

Clarissa (Clary) Adele Fray/Fairchild is the protagonist of six books in the series The Mortal Instruments and Valentine's daughter. As a Shadowhunter, Clary has a talent to see through magical illusions: "It's her gift, to see the beauty and the horror in ordinary things" [7].

The author decided to show us her abilities through the name Clarissa, which has English, Italian, and Portuguese roots. It is derived from the German name "Clarice", which was in turn from a medieval French form of "Claritia," a derivative of "Clara" [9].

The name itself is obtained from the plant of the same name: "salvia sclarea", wherein the Latin name "sclarea" is derived from the adjective "clarus" which means "clear, bright, and famous". The plant is also called "Clear Eye" and "See Bright" (seeds of this plant have been used for clearing the sight) [10].

Clary's middle name "Adele" was in honor of her maternal grandmother, as a symbol of relationship with her ancestors. However, it may be decoded as a female given name, came from a Germanic word "noble" [11].

Her mundane surname "Fray" was derived from the ancient Anglo-Saxon culture. It was given to a person who was referred to as the fry, which literally means "free". As we may notice from the text, Clary is childishly stubborn; she has her own opinion about everything and chooses independence.

Moreover, author described her as a quite short, just a little over five feet tall, with the carrot-colored hair and face full of freckles. That may be explained by the fact that "Fray" comes from the Middle English word fry, meaning "small person", or "child" [12].

Jonathan Christopher (Jace) Herondale (also referred to as Wayland, Morgenstern, and Lightwood). While in general he has no official birth name, he is known as Jace Herondale. Jace is the nickname, short form of "Jason" [13] obtained from his first assumed name, Jonathan Christopher. Cassandra Clare begins our acquaintance with words of Jonathan himself: "I don't know who I am. I look at myself in the mirror and I see Stephen Herondale, but I act like a Lightwood and talk like my father - like Valentine. So I see who I am in your eyes, and I try to be that person, because you have faith in that person and I think faith might be enough to make me what you want" [7].

During the whole story, his confusion in choosing "who he really is" was vividly shown through the prism of several surnames that were used to identify him, among of them are: Wayland, Morgenstern, Lightwood, and, finally, Herondale [14].

"Jonathan" comes from a Hebrew word meaning "God gave" [15] and the short form "Jace" has a Hebrew origin meaning "the Lord is salvation" [16]. His middle name "Christopher" derived from the Late Greek

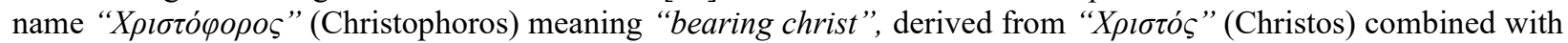
" $\varphi c ́ \rho \omega "$ (phero) meaning "to bear, to carry". Early Christians used it, expressing that they carried Christ in their hearts [8]. 
His names contain the God's part, as due to Valentine's experiments while he was still in his mother's womb, he has in his veins angel blood of Raziel and Ithuriel. It contributes to his superiority in certain fields and other enhanced aspects beyond the normal Shadowhunter parameters.

Magnus Bane is an 800-year-old High Warlock born to a Greater Demon, prince of demons, Asmodeus, and a Dutch-Indonesian mother. As a character, Magnus is a closed and unpredictable. No one can say for sure what is going on in his head. The warlock acts according to only the rules known to him; in everything he seeks profit and does not want to initiate others into his plans. Since demonic blood flows in his veins from Asmadeus, the prince of demons and the fallen angel, Magnus inherited immortality and an unlimited source of power, in the form of a blue flame. He is also able to cast spells and perform summoning rituals. Magnus Bane is an extremely powerful warlock who can destroy anyone who dares to stand in his way at the snap of his fingers.

Apparently, name Magnus is a reference to the term Magnus effect - a phenomenon where an object in motion suddenly changes its path and "goes somewhere you would never have expected" [17]. In addition, "Magnus" is also a Late Latin name meaning "great" [18].

Surname Bane hides multitudinous possible meanings. "Bane” as a boy's name has the Slavic origin, and can be an alternate variant of the name "Branislav", that represents meaning "glorious defender" [19; 20].

From Old English or Germanic derivatives it can also mean "killer" or "angel of death" [17]. According to Merriam-Webster Dictionary, bane was interpretated as "death, destruction, woe, poison, killer, slayer", and as a second meaning it is "a source of harm or ruin-curse" [21].

As you see from the above explanation, the author absolutely accurately managed to convey the difficult character of the hero and his increased abilities. On the one hand, Magnus appears before us as a true savior, ready at all costs to help his friends, but on the other hand, the writer emphasized his demonic origin, which implies erratic behavior and an unequivocal hint of narcissism. Magnus Bane is multifaceted; he is both dangerous and beautiful at the same time.

Simon Lovelace, born Simon Lewis, is Clary Fairchild's best friend. He is always ready to help and listen to her thoughts. In this purpose, author makes an accent on this strong connection with Clary through the name

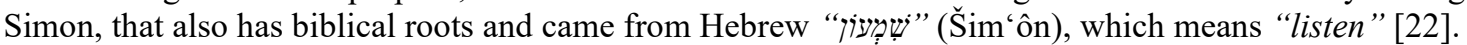

In compare with Niphilims and other creatures of magical world Simon looks extremely inconspicuous, weak and powerless. At the very beginning of the books, he was described as just a typical teenager without any specific abilities. Cassandra Clare vividly showed this with the help of other characters. For example, warlock Magnus - while they were on a mission together - made no effort to remember his name and called Simon by several other kind of similar names such as Sherwin, Smedley, Sheldon, Seamus, and Sherlock [7].

However everything changes dramatically when Simon became a vampire who can walk under the sun and through an excess concentration of angel blood, compared to other Shadowhunters, got a variety of enhanced physical, magical and mental abilities. Even angel Raziel addressed to him as "Simon Maccabeus" or "Warrior of Heaven", referring to his faith and his bravery [22].

Nonetheless, there is another reason for such name choice. As we know from the books, Simon was a Daylighter, and due to this specific vampire ability he gained the power to bring the dead back to life. "Maccabeus" origins of the biblical Book of Maccabees, sections of which address both the deaths of faithful people asked to renounce their religion and the manner in which the dead should be properly commemorated. There are praying texts for a happy afterlife of the dead souls, persecuted for their religion. In medieval France, representations of these passages were performed as a procession or dance which became known as the "dance of death" or "dance Maccabee" [23].

Thus, the author, through the technique of allusion, again conveyed the entire spectrum of his new abilities, thereby creating the final portrait of the character in the readers' minds. In this case, we can also trace the development of Simon's image from a barely noticeable, almost uninteresting teenager to a superhero endowed with unimaginable power.

Conclusions. On the materials of the above analyzed examples we can see that studying the modern English prose through the perspective of onomastics helps to see the inner psychology and brilliance of the author. The proper names in the literature possess a special content that differentiate those texts from scientific ones. There is a hidden meaning in proper names, they become an integral part of the story, allow readers to look into the depths of the character. Consequently, their investigation, detecting any patterns, understanding the lexico-semantic orientation is the first step to comprehension the aesthetic function of the artwork.

\section{References}

1. Nazarenko O. V., Rakitina A. A. Semantic content of proper names in modern fairy-tale discourse. Socio-humanitarian aspects of the development of modern society: materials of the All-Ukrainian scientific conference of teachers, graduate students, teaching staff and students, Sumy: Sumy State University, 2014. P. 51-53. SumDU Repository. URL: http://essuir.sumdu.edu.ua/handle/123456789/34625 (accessed date: 23.09.2020)

2. Boka O. V, Barsuk T. V. Actualization of proper names in fairy-tale discourse. Bulletin of Sumy State University. Philology series. No. 1. 2008. P. 9-14. SumDU Repository. URL: http://essuir.sumdu.edu.ua/handle/123456789/1465 (accessed date: 23.09.2020)

3. San Román Villar, Marta "All the Stories Are True": Intertextuality in Cassandra Clare's Shadowhunter Chronicles. Grado en Estudios Ingleses. Valladolid. 2017/2018. 38 p. UVaDOC. URL: http://uvadoc.uva.es/handle/10324/33430 (accessed date: 23.09.2020)

4. Shadowhunters name meanings (part one). Amino. URL: https://aminoapps.com/c/shadowhunters/page/blog/shadowhunters-namemeanings-part-one/b47X_7GhouX72Ev3BJ0GxdPGzDwNKMzpZZ (accessed date: 23.09.2020) 
5. Morgenstern History, Family Crest \& Coats of Arms. House of names. URL: https://www.houseofnames.com/morgenstern-familycrest (accessed date: 23.09 .2020 )

6. Sebastian Morgenstern. The Shadowhunters' Wiki. URL: https://shadowhunters.fandom.com/wiki/Sebastian_Morgenstern (accessed date: 23.09 .2020 )

7. Cassandra Clare. City of Bones. The Mortal Instruments. URL: https://themortalinstruments.org/city-of-bones-chapter-1/ (accessed date: 23.09 .2020 )

8. Christopher. Behind the Name. URL: https://www.behindthename.com/name/christopher (accessed date: 23.09.2020)

9. Clarissa Adele "Clary" Fairchild. The DaWinter Universe Wikia. URL: https://dawinterverse.fandom.com/wiki/Clary Fray (accessed date: 23.09 .2020 )

10. Clary. Behind the Name. URL: https://www.behindthename.com/name/clary/submitted (accessed date: 23.09.2020)

11. Adele. Dictionary.com. URL: https://www.dictionary.com/browse/adele?s=t (accessed date: 23.09 .2020 ) 23.09.2020)

12. Fray Surname History. House of names. URL: https://www.houseofnames.com/Fray-history?A=54323-292 (accessed date:

13. Jace. Behind the Name. URL: https://www.behindthename.com/name/jace (accessed date: 23.09.2020)

14. Jace Herondale. The Shadowhunters' Wiki. URL: https://shadowhunters.fandom.com/wiki/Jace_Herondale\#cite_note-22 (accessed date: 23.09 .2020

15. Jonathan. Dictionary.com. URL: https://www.dictionary.com/browse/jonathan (23.09.2020)

16. Jace. Nameberry.com. URL: https://nameberry.com/babyname/Jace/boy (accessed date: 23.09.2020)

17. Magnus Bane. The Shadowhunters' Wiki. URL: https://shadowhunters.fandom.com/wiki/Magnus_Bane\#cite_note-BTEN-31 (accessed date: 23.09 .2020 )

18. Magnus. Behind the Name. URL: https://www.behindthename.com/name/magnus (accessed date: 23.09.2020) 23.09.2020)

19. Bane Pronunciation: n/a. Baby name wizard. URL: https://www.babynamewizard.com/baby-name/boy/bane (accessed date:

20. Branislav. The Name Meaning. URL: https://www.thenamemeaning.com/branislav/\#ixzz6b9KxSyvV (accessed date: 23.09.2020)

21. Bane noun (1). Merriam-Webster. URL: https://www.merriam-webster.com/dictionary/bane (accessed date: 23.09.2020)

22. Simon Lewis. The Shadowhunters' Wiki. URL: https://shadowhunters.fandom.com/wiki/Simon Lewis\#cite note-CoLS-7 (accessed date: 23.09 .2020$)$ 23.09.2020)

23. Maccabees plural noun. Merriam-Webster. URL: https://www.merriam-webster.com/dictionary/Maccabees (accessed date: 